\title{
PUERTO RICO: THE FUTURE IN QUESTION
}

[Received May 2nd 2019; accepted October 9th 2019 - DOI: 10.21463/shima.13.2.13]

\section{Adriana Garriga-López}

Kalamazoo College, Michigan <agarriga@kzoo.edu>

\begin{abstract}
This essay is based on ethnographic fieldwork carried out from December 2017 to August 2019. In it, I reframe the condition of disaster that Puerto Rico faced after Hurricane Maria through a consideration of the political economy of the post-hurricane crisis. I consider the ways that Puerto Rico has become a highly active extractive zone on the periphery of US empire and the role of Maria in these transformations, including in terms of the politics of knowledge production. I investigate the notion of auto-gestion for the ways it acts as both a mode of survival within the permanent crisis, and as a quandary of decolonisation that sometimes buttresses colonial state power. I also document some of the autonomous efforts that were part of the recovery, questions that people who survived the storm continue to confront in their everyday lives, and the importance of resource sharing strategies that exist outside the commodity market. Ultimately, enacting food sovereignty within a colony is a paradox, but one that harbours transformative potential. What is transformed after Maria? What changes lie ahead? What role will small farming and climate change play? Puerto Rico's future remains in question.
\end{abstract}

KEYWORDS: Puerto Rico, Decolonisation, Disaster, Food, Sovereignty

\section{Introduction}

This essay places the unfolding of political events in Puerto Rico after Hurricane Maria within debates about decolonisation, including aspects of the recovery and the multitudinous protests that took place during the so-called Puerto Rican Summer. Fundamentally, this essay argues that the possibilities for effective disaster preparedness and recovery in Puerto Rico are severely hampered by the reality of ongoing US colonialism. While the future of these islands remains uncertain, some cultural aspects of disaster recovery respond to the force of decolonisation as a paradigm for transformation by enacting modes of solidarity between people. In that sense, despite the deeply flawed process of recovery from hurricanes Irma and Maria and the ways in which imperial power was reasserted through military control and political manoeuvering, disaster recovery can also represent an opportunity for decolonisation. At the very least, disasters can create opportunities to put decolonising narratives and approaches to the test in the process of reconstruction.

I carried out ethnographic research in Puerto Rico (Figure 1) intermittently from December 2017 to July 2019, interviewing, visiting with, and observing small farmers as they engaged in the recovery. In the course of that research, some Puerto Ricans I spoke with said, "we have 
already lost Puerto Rico," echoing a sense of topalgia (the loss of a sense of place). Others said, "we've lost Rincón" or "we've lost Old San Juan." Still others said "we've lost Vieques". What does it mean to say we have "lost" these places in the context of 121 years of US colonialism and 406 years of Spanish colonialism before that? If they're "lost" how did we lose them and to whom or what did we lose them? Vieques, Rincón, and Old San Juan are sites whose history must be told through the intertwining of war and tourism as political economic and cultural formations. Neither soldiers, nor tourists are new in these areas. So, what is the reason for the sense of loss that some Puerto Ricans feel? And, did this sense of loss animate the massive protests of July 2019 (Tormos-Aponte, 2019) known as the Puerto Rican Summer? Is Puerto Rico moving towards or further away from decolonisation? These questions cannot be answered without studying the intensification of extractive economies (Gómez-Barris, 2017) and forms of disaster tourism (Thomas, 2014), gentrification (Gould and Lewis, 2018), and predatory investment (Villanueva, Cobián, and Rodríguez, 2018) that occurred after Hurricane Maria (Molinari, 2019). Economic modes of extractivism, austerity, and disaster capitalism increasingly intertwine in Puerto Rico, where at present we are witnessing the privatisation of the public sphere on a massive scale. These dynamics have produced a clash between the state and ordinary people that threatens their long-term survival on the islands; but people are finding ways to resist.

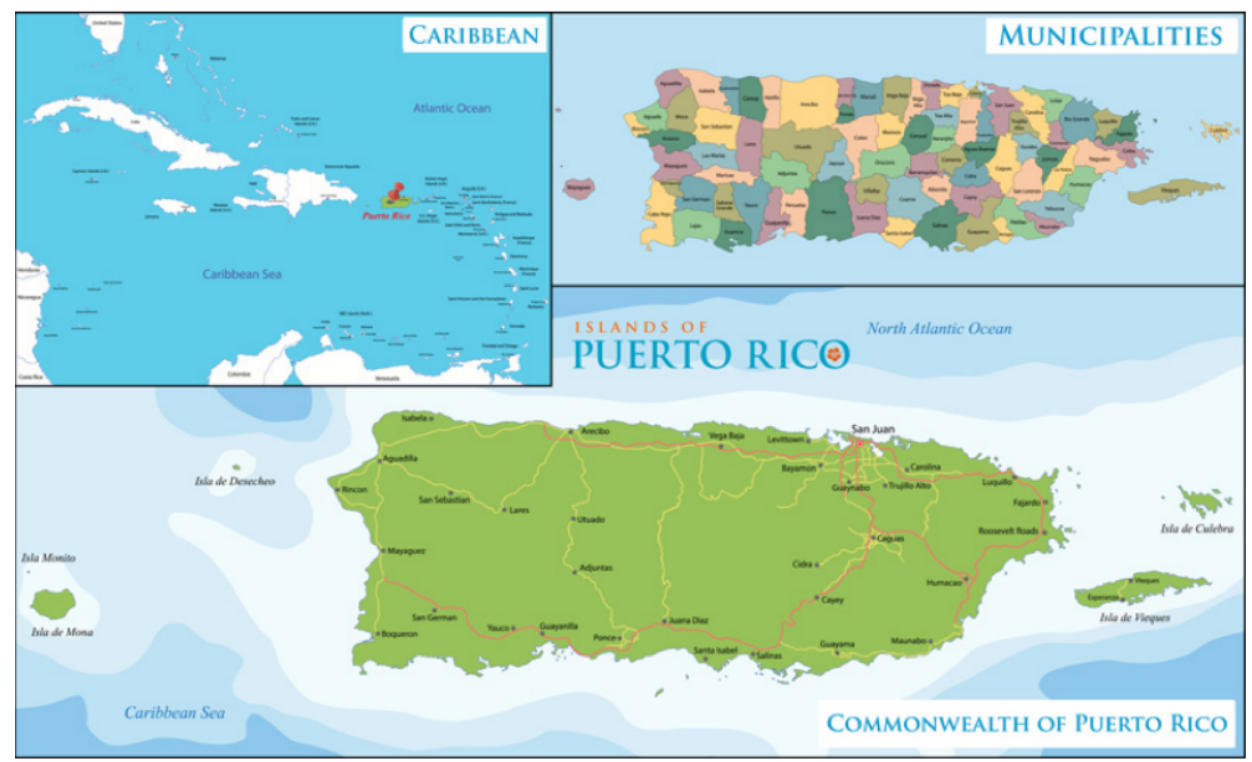

Figure 1 - Maps of Puerto Rico and its position in the Caribbean (Source: Islandsofpuertorico.com)

\footnotetext{
${ }^{1}$ I owe this concept to Susanna Hoffman of the International Commission on Risk and Disaster, who organised a panel for the 117th Annual Meeting of the American Anthropological Association in 2018 entitled, 'Nostalgia (Pain of Past), Ecalgia (Pain of Home), Topalgia (Pain of Place): Deciphering the Loss and Pain of Displacement and Resettlement - An Overview'. Although I was not able to attend the conference in person, I retained some of her framing for the panel in this essay.

${ }^{2}$ Rincón is a small town on Puerto Rico's northwest coast.

${ }^{3}$ Old San Juan was the Spanish colonial capital and continues to be the US American colonial capital of Puerto Rico, as well as a highly popular tourist destination and cruise ship port.

${ }^{4}$ Vieques is a small island municipality eight miles off the eastern coast of Puerto Rico's main island.
} 
The conditions of possibility for ethnographic engagement in Puerto Rico were transformed by the passage of Hurricane Maria on September 2oth, 2017. Due to its location, hurricanes are a natural part of Puerto Rico's ecosystem. While many hurricanes have crossed the Puerto Rican archipelago, Hurricane Maria was the largest to strike since 1928. Since Maria, anthropological labour on the islands cannot proceed without considering the material and symbolic effects of the storm in any given field under study, including this affective zone of loss. Rather than being the sole cause of this shift in ethnographic or psychic conditions, however, the events of the 2017 hurricane season in Puerto Rico mostly intensified and exacerbated a painful process of socio-political decomposition that was already well underway.

Puerto Ricans in the diaspora also felt the impact of Hurricane Maria. All over the globe, Puerto Ricans worried about friends and family on the islands; sent medicine, food, water, money, generators, solar-powered tools, and other supplies; and organised relief efforts. Thus, while we felt our losses, we also learned to feel new forms of power and solidarity. And yet the terms of that solidarity are themselves hotly contested.

Critiques of value extraction under disaster capitalism (Klein, 2007) have been extended to scholarship and knowledge production, implicating academics in the need to decolonise our approach to researching disasters (Gaillard, 2018). Additionally, because the long-term effects of colonialism make disasters so much more probable and destructive and recovery so much harder, analyses of how best to prepare for or respond to disasters often lead to a consideration of the relative benefits of decolonisation. Yet, it is worth remembering that decolonising research methods and approaches to studying or preparing for disaster is not necessarily the same thing as decolonisation itself (Tuck and Yang, 2012).

Puerto Rican scholars and organisers based in institutions outside of Puerto Rico have faced new ethical dilemmas, as well as increased scrutiny and calls for accountability from survivors of Hurricane Maria on the islands who have watched with not undue suspicion how their experiences and activisms become fodder for articles, books, and news items that add value to the profiles of continental scholars and organisers, myself included. The years after Maria have brought a research and media boom to Puerto Rico that is an example of how knowledge production is part of the value generated through disasters under extractive regimes (Fletcher, 2019), even though, of course, many scholars were also studying and writing about Puerto Rico before 2017, myself included (also see Garriga-López, 2018). Critiques of coloniality have long contained considerations of the ways academia reifies imperial power (Díaz-Quiñones, 1991), and Eurocentric (Maldonado-Torres, 2016) or orientalist epistemologies (Said, 1978). At the same time, critical and anti-colonial scholarship on these topics is needed now more urgently than ever, and is to a significant extent carried out by Puerto Ricans on the islands and in the diaspora. Because of the crisis that afflicts scholars and research institutions on the island (Brusi-Gil de Lamadrid, 2011), however, island-side scholars often have far fewer resources at their disposal and must make greater sacrifices to reach research and publication goals. In turn, diasporic Puerto Rican scholars are faced with an influx of (mostly white) US American scholars whose interest in Puerto Rico results primarily from an engagement with Disaster Studies and tends to be episodic and technocratic, rather than deeply rooted, long-term, semiotic, and/or accountable to the communities under study. Although these are not unfamiliar dilemmas for anthropologists (Panourgia, 2011; Ramos-Zayas, 2010; Lauria-Pericelli, 1989), the interdisciplinary nature of Disaster Studies compounds the difficulty. Additionally, the rather extreme hierarchies and strictures of academic privilege reproduce themselves within 
this "problem-space" (Scott, 2004) through the social dynamics of research funding, power, and prestige. Within this tense space, I have engaged with food justice, queer feminism, and the agro-ecology movement in Puerto Rico as sites of decolonial action in the colonial present. $^{5}$

\section{Necropolitical Colonialism}

Puerto Rico was annexed in 1898 under the US congressional doctrine of territorial unincorporation. It was thereby considered as belonging to, but not a part of the United States, or as "foreign, in a domestic sense" (to quote the title of Duffy Burnett and Marshall's 2001 anthology on Puerto Rico). The Estado Libre Asociado (ELA or the Associated Free State) of Puerto Rico was created 1952 after a Constitutional Assembly penned a constitution that was itself a federal law. Beholden to the US Constitution and edited by Congress, the Puerto Rican Constitution did not create a new polity, but merely established political structures for limited self-governance (Ayala and Bernabe, 2009 and Cabán, 2002). In 2016, the US Congress passed the Puerto Rico Oversight, Management, and Economic Stimulus Act, known as PROMESA (H.R. 5278, 2016), which established a Fiscal Control Board that limits government spending and has budgetary veto power over all locally-elected governmental representatives (Cabán, 2018). The Board was found to have been unconstitutionally appointed by a federal appeals court in early 2019 (Llórens Vélez, 2019b), but the appointments were allowed to stand and re-nominated by President Trump (Llórens Vélez, 2019a).

PROMESA reinscribed the congressional doctrine of unincorporation (Garriga-López and Uperesa, 2017), destroyed the façade of democracy (Lewis, 1963), and reified territoriality, which is to say coloniality (De Onís, 2018) in US federal law. It also orchestrated a financial consultocracy under the auspices of the Fiscal Control Board (or La Junta, as it's called in Puerto Rico). All this was in place before Hurricane Maria hit (Rodríguez-Díaz, 2018) and before the election of Donald Trump, whose administration brought with it a return to the imperialist policies of the Monroe doctrine (Newman, 2019), which stipulates the inevitability and purported righteousness of US control over the entire American hemisphere, with an emphasis on the Caribbean and Central America (Oliva Campos and Prevost, 2019).

Despite rhetoric from the pro-statehood camp, Puerto Rico's full incorporation into the United States as a state now seems highly unlikely. In 2016, Puerto Rico's New Progressive Party (PNP) promised an energetic push to garner support for Puerto Rico to become the 51st state of the United States of America under the leadership of Governor Ricardo Roselló. Yet Roselló was forced to resign after leaked phone messages between him and his cabinet exposed the rancid and corrupt internal culture of the administration. He did so on August 2nd, 2019 in utter disgrace after weeks of protests that united the Puerto Rican archipelago and diaspora in a shared sense of indignation (Mazzei and Robles, 2019). These protests were notable for their size and for their expressly feminist and queer character (Morales, 2019), marking a political watershed.

\footnotetext{
${ }^{5}$ This research was supported by two Faculty Research Grants from the Arcus Center for Social Justice Leadership at Kalamazoo College and a Quick Response Grant from the Natural Hazards Center of the University of Colorado.
} 
The arrests on federal charges of five of his appointees (Allyn, 2019), including that of the highly contentious Secretary of Education, Julia Keleher, who stands accused of 32 counts of fraud (Vincens, 2019), contributed significantly to the anger that ignited the protests that led to Roselló's hurried exit from the islands (Alvarado and Suárez Torres, 2019). This was followed by former Resident Commissioner and Junta counsel Pedro Pierluisi's furtive swearing-in as Governor in his sister's San Juan apartment on August 3rd, 2019 that, in turn, led to a Puerto Rico Supreme Court decision declaring the unconstitutionality of his oath and to his swift departure from the islands. In his stead, former Secretary of Justice, Wanda Vásquez, herself facing a deficit of credibility after being investigated for fraud by the Puerto Rican Senate earlier in the year, was sworn in as Governor on August 7th, 2019 (Gonzales, 2019). All of this turmoil has led to a tremendous loss in momentum for the PNP, making statehood by electoral means appear - at a time when birthright citizenship as a whole is under attack and anti-Latinx violence and discrimination are at an all-time high - even less likely than before Ricardo Rosellós election (Ramos, 2019). But neither is Puerto Rican sovereignty through independence allowable under Trump's 'America First' policies. The only way that independence seems closer in the Trumpian era is as a result of racism.

Despite all the suffering that Puerto Ricans endured after Hurricane Maria, surviving the loss of approximately 4,645 lives (Kishore, et al, 2018), and the longest blackout in American history (Negrón-Muntaner, 2018), Puerto Ricans in Puerto Rico effectively still do not have real political representation in the institutions of power that decide their affairs, neither in Washington DC, nor on the islands, where the Fiscal Control Board reigns supreme.

The thin illusion of democratic rule created by the Constitutional process and the Muñocista period of the mid-2oth Century has disintegrated; the ELA has reached its "obsolescence" and colonial governmentality has devolved into a "necropolitical logic" that deigns the population excessive and abandons it to die of neglect (Cortés, 2018). The idea of Puerto Rico as a "social laboratory" (Lapp, 1995) where science would guide progress and modernisation is an indisputable failure, given the contemporary economic and environmental panorama, and the high rates of violent crime. The notion that Puerto Rico could be a "showcase of democracy" (Underhill, 1961) that demonstrates for the rest of Latin America the benefits of US liberal capitalism over leftist ideologies is completely bankrupt. Residents of the islands are yoked to over 76 billion dollars in external debt, except for the very wealthiest, who pay almost no taxes under state incentives meant to attract wealthy US Americans. Local party politics have become a side show, a kind of melodramatic saga like the telenovelas that still dominate certain Spanish-language TV schedules. Frustration with this party system also drove the massive protests seen during July 2019, with more than half a million people marching on July 22nd, 2019 (Acevedo, Gutiérrez, and Ramos, 2019).

No one can reasonably deny that Puerto Rico is a colony of the US (Trías Monge, 1997). Ultimately, real political power lies with Congress (and the Fiscal Control Board as an entity created by US Congress to supervise the Puerto Rican fiduciary process) and with the Puerto Rican people, who may not be legally sovereign over the land, but who are capable of enacting popular control over the territory. Perhaps the death of the ideology of the Associated Free State (ELA) is to be celebrated because it brings us closer to an honest assessment of the relationship between the islands and the US. In that spirit, it seems, a death notice for the ELA was published in a local newspaper after the passage of PROMESA in 2016 (Primerahora, 2016: online - Figure 2). 


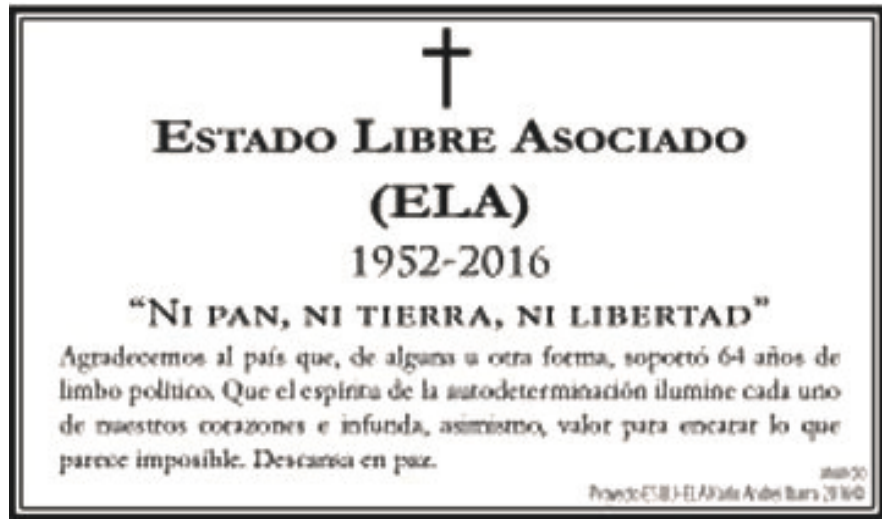

Figure 2 - Satirical death notice for ELA (translation - "Neither bread, nor land, nor liberty.

We are grateful to the country that has in one way or another withstood 64 years of political limbo. May the spirit of self-determination illuminate each of our hearts and give us courage to do the impossible. RIP.") (Primerahora, 2016: online).

Analogously to the death of the ELA, the dream of statehood some Puerto Ricans had was effectively killed by the PNP, which was to be its champion. The death of statehood is ultimately also a productive loss for Puerto Rico. Even so, the injury and suffering caused to millions of people who found they were without reliable state or federal emergency aid in the wake of Puerto Rico's worst weather-related disaster in almost a century produced a deep and lingering sense of loss (Scaramutti et al, 2019; Orengo-Aguayo, Stewart and de Arellano, 2019). For some this sense of loss has to an extent transmuted into anger and righteous indignation, spurning them into action. But for others the whole episode still lingers, feels like an open wound, or like Maria just happened. Two years after Maria, research-based scholarship (Bonilla and Lebrón, 2019) and investigative journalism (Klein, 2018) have illuminated and substantiated the massive scale of the crisis the storm precipitated in Puerto Rico (García-López, 2018). But the political foundation that was the condition of possibility for this disaster and the Trump administration's open hostility to Puerto Rico (McCune, et al, 2018) have not changed (Klein, 2019).

\section{¿Estamos bien? Are we OK?}

Health and wellbeing mean a lot of different things to different people in Puerto Rico today. Immediately after Maria, for many, health meant simply having survived, being safe and being able to keep loved ones safe, having water to drink, having access to food, somewhere to sleep, and a roof over their heads (Benach et al, 2019). In the months and years after Maria, health still means having access to these things, but it also includes the stability of basic social services like education and healthcare, which are two governmental areas that have seen large cutbacks directed by the Junta.

Federal funding for health care in Puerto Rico has been capped by Congress since 1968 to a much lower rate than that in the fifty states. Currently about $13 \%$ of spending is funded by federal dollars (Puerto Rico Report, 2019). This includes Medicaid and Medicare, even though Puerto Ricans pay into these programs at the same rates as their counterparts in the fifty states (Mulligan, 2014). Since its inception, this funding cap has been one of the most 
crushing facets of US colonial domination on the islands. The resulting state of permanent resource insufficiency undergirds and feeds the assemblage of social, technical, and clinical knowledges, and speculative neoliberal modalities mobilised in response to the manifold crises in Maria's wake. At present, that funding cap is being subsidised partially by disaster relief funds, and partly by grants extended to Puerto Rico after Obamacare was rolled back to exclude Puerto Rico (and the other US territories). These funds were set to expire on zoth September 2019 creating a "Medicaid cliff" that could further devastate the island (Puerto Rico Report, 2019).

Puerto Rico has experienced large scale population movements several times since the US invasion in 1898, most notably during the 1950s (Duany, 2003). The driving factor has consistently been high unemployment rates in Puerto Rico and the comparatively higher availability of jobs in the continental US (Ayala, 1996; Caraballo-Cueto, 2015). The population of Puerto Rico has declined from a peak of almost 4 million people in the early 2000 so approximately 3.2 million people in 2018 (Mora et al, 2018; Meléndez and Venator-Santiago, 2018). The most recent wave of emigration is directly related to Puerto Rico's financial crisis beginning in 2006, with an increase in numbers after the passage of PROMESA in 2016 and especially after Hurricane Maria in 2017 (Cabán, 2018; Hinojosa, 2018; Mora, et al, 2018). Nearly 130,00o people left Puerto Rico between July 2017 and July 2018 (Sutter, 2018), including large numbers of doctors and other medical professionals leaving patients with few options, especially for specialised care (Parés Arroyo, 2018; Patron, 2017). Many people with complex health needs, as well as those with chronic illnesses have also left the islands in order to find treatment in the United States or elsewhere (CCR, 2017; Margolis, 2016).

In such a circumscribed sociopolitical space, projects run by charitable or community organisations mostly reiterate and reinforce the conditions of structural and semiotic violence that are the hallmark of U.S. colonialism on the islands. Even when such projects articulate themselves expressly in opposition to structural violence, they are generally able to effect only palliative and fragmentary action (Joseph, 2002). In contrast, or as a result of such opacity, autonomous modes of organising seek to establish and strengthen social bonds that can generate momentum toward self-directed action and stability in particular neighbourhoods, marginalised zones, or localised areas (Rodríguez-Soto, 2018). Affinity groups whose members are willing to work together with little external support organised as "brigades" were sometimes the most efficacious method of achieving community health and disaster recovery goals quickly in isolated areas. In the weeks after Maria, these affinity groups were in some cases the first to reach isolated communities, especially in the central highlands (Tormos, 2018). As these examples illustrate, the clash between state governmentality and autonomous organising is a matter of survival. Indeed, after Maria survival itself became a supremely political act.

\section{Auto-gestión or Autonomous Organising}

What Puerto Ricans call auto-gestión, I translate here as autonomous organising. Simply stated, this phrase refers to the ways that ordinary people organised to help each other during the post-Maria crisis "at the margins of both the local and federal government" (Llenín Figueroa, 2019: online). Autonomous groups engaging in solidarity work in the post-disaster context were able to "promote alternative sociabilities capable of exceeding the normative worlds of colonialism and private property" (Pérez-Lizasuain, 2018: 53). Auto-gestión was about more than just physical recovery activities, however, as different structures and 
modalities of care were created out of an awareness of the manifold needs of the community. Thus, different groups on the islands created cost-free events that could "emphasize individual and collective care for one another in a holistic sense" (Lebrón and Arbona, 2018: online), legal counselling (Noboa Ortega and Soto Arzat, 2018), and even vocalisation therapy. ${ }^{6}$ Artists were also central to these events, providing free entertainment through theatre, music, and cathartic performances dealing with the experience of the hurricane (Marston-Firmino, 2019). Thus, the term auto-gestión became a rallying cry for broad coalitional work that could bridge entrenched political, social, and other divides through collective action on unifying issues. Under the rubric of auto-gestion, people were able to help their friends and neighbours, as well as strangers. Organising as mutual aid societies, people developed a new sense of their own capacities.

But who is the subject of this self-empowerment or auto-gestion? Who is the subject quien se auto-gestiona, o quien se gesta - who self-gestates or is born through it? Is it THE People of Puerto Rico or all people living in Puerto Rico? Is it the Puerto Rican diaspora (Hinojosa, 2018)? Is it anarchists (Meléndez-Badillo, 2019)? Whomever it is that could be said to be the historical subject of this becoming, the main problem with auto-gestion or autonomous organising is the problem of the state. While mutual aid as an organising model can help people survive situations of disaster (Feuer, 2012), extreme impacts often present the need for large scale functions that require resources normally beyond what individual communities can muster, creating severe challenges to the mutual aid model. In addition, the federal and local state governments have a legal responsibility to serve the populations who fund emergency services with their tax dollars, which includes Puerto Ricans.

Yet for most people in Puerto Rico, the state seems like an obstacle to survival (Ora Bannan, 2017). The process of attaining basic social services was difficult (to say the least) before Maria and is nothing short of Kafkaesque after. It took the US military eight days (Anders and Bollettino, 2018) to arrive in Puerto Rico after Hurricane Maria and it took the USS Comfort 39 days to dock in San Juan (Hooper, 2017). The Federal Emergency Management Agency (FEMA) was largely distinguished by its absence in the hardest hit parts of Puerto Rico. Their influence was strongly felt however, in the sea and air ports, where they confiscated shipments containing generators, food, water, and other aid (Sullivan, 2018). What food FEMA and the military did distribute once they arrived was far below nutritional standards (Colón-Ramos, et al, forthcoming 2019). I saw boxes full of Cheetos and applesauce distributed by FEMA to homes in Utuado, Dinty Moore stews and crème sandwich cookies in single serving units distributed by the Army in Vieques, and children collecting water from roadside streams in the mountains of Adjuntas.

Today, constructing alternative spaces of knowledge exchange (along with para-state or extra-legal forms of socio-economic life based on the principle of solidarity) makes living in Puerto Rico possible for all but the most privileged (Rodríguez Soto, 2018). The extractive view cannot fully account for this other Puerto Rico becoming-free at the razor's edge of neoliberal precarity, because the fluid, dynamic, paradoxical, and collective process of building and enacting solidarity amid chaos is necessarily beyond its epistemic grasp. Nevertheless, the abandonment of the state (or participation in state-based processes) combined with the contraction of the welfare state puts greater pressure on community groups and generates

\footnotetext{
${ }^{6}$ A group of women musicians known as Sanar Cantando (Healing by Singing) led by Mariana Lima Sofía and Shanti LaliTa have been performing concerts that are healing rituals for survivors of Hurricane Maria in Puerto Rico since 2017.
}

Shima Volume 13 Number 2019

- 181 - 
dependence on the charity-industrial complex, with strings tied to foundation and grant funding.

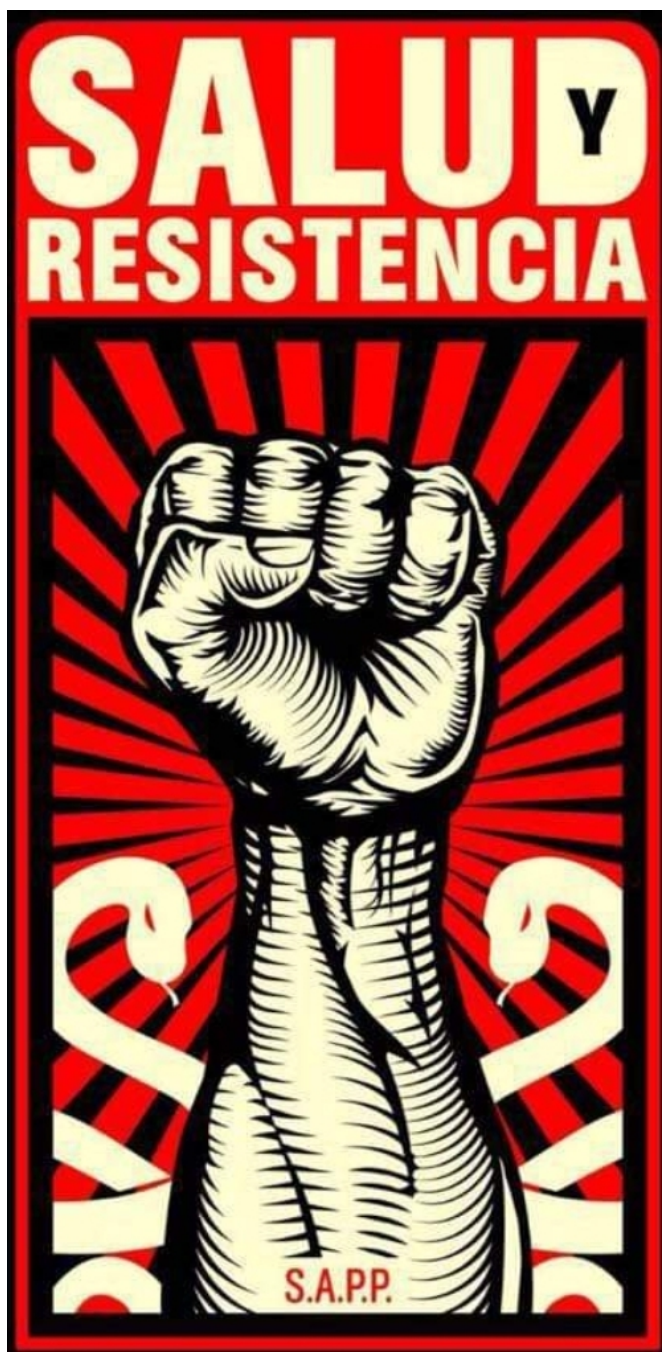

Figure 3 - Poster created by the group Acupuntura Pa'l Pueblo ('Acupuncture for the People'). Reproduced with permission.

The US and Puerto Rican governmental responses to Hurricane María were totally inadequate (Karlin, 2017); so inadequate that they made both state and federal power at times appear to be almost irrelevant during the first few weeks after Maria, when no aid at all had arrived yet for most, making October 2017, by all accounts, the most difficult and painful month of the post-hurricane period. It was also during this time that autonomous organising made its biggest impact in the recovery, when anarchists and other leftists organised a wide variety of efforts from community kitchens (Laguarta Ramírez, 2018) to solidarity agricultural brigades (McCune, et al, 2018) to respond to the enormous need for aid, support, and healing 
that existed in Puerto Rico and was largely being ignored by government agencies. We can easily see the necessity of having local emergency preparedness plans in place and of having locally specific responses to disaster. Yet, we must also consider the problems of and limitations to auto-gestion in the island context, including the ways it might encourage a politics of purity around the question of who deserves aid and even the limitations of geography because of the ways disasters can devastate entire islands. In addition, it behooves us to consider the ways that CBOs and NGOs are tied to imperial governance though they employ the language of community and non-governmentality. What are the conditions of visibility that make legible the connections between the state and non-state actors, between anarchists and decolonial praxis, between queer feminism and agroecology?

\section{Maria Made Us Strong}

The small farming movement in Puerto Rico is a popular topic among activists and academics because of the yearning for sustainability and self-determination that it represents. To hungry leftist eyes, cultures of agro-ecology in Puerto Rico offer the promise of a recalibration of modes of anti-colonial resistance away from political orthodoxies and toward creative forms of organisation that are implicitly and sometimes explicitly in opposition to US sovereign power and the interests of global capital. But romanticising small farming as the answer to unending colonialism can also lead to forms of denialism and cruel optimism (Berlant, 2011) that can actually make Puerto Ricans more vulnerable to disaster.

Maria hit hard, with the force of something brutally familiar-really intimate. The effect was too intimate, reaching down into existential layers of Puerto Ricanness and my own genealogy. María is my middle name. It was also my mother's name-María. She told me once how in the 1970 s she and her feminist friends in the Puerto Rican Socialist Party laughed about that scene in the 1961 film West Side Story when Tony goes looking for the Puerto Rican girl he's in love with in Spanish Harlem and he sings, "Mariiiiaaaaa!," like she's all special. Mami said she and her friends used to joke that not one, but all the Puerto Rican girls in the barrio had looked out their tenement windows and answered, “QQueeeé?" (Whaaat?!)

After Irma and Maria, many Puerto Ricans were isolated, cut off from access to refrigeration and stores and with little access to fresh food and clean water. For months, many struggled to put food on the table. It could have been worse, as multiple hurricanes in the Caribbean basin following closely upon one another (as was the case in 2017 and 2018) suggest that relief supply chains that flow exclusively from north to south could be rendered useless by a scenario wherein more than one hurricane blocks relief routes. As it was, Puerto Rico's subjection to the shipping restrictions ensconced in the Jones Act (H.R. 10378, 1920) operated as a de facto blockade after Maria (Yglesias, 2017), allowing aid to arrive exclusively from the United States. ${ }^{7}$

Understanding how people survive and resist the effects of colonial violence, resource extraction, disaster, and climate change in Puerto Rico requires a historically grounded critique of land ownership (Dietz, 1986), water rights (Hunter and Arbona, 1995), labour (Mintz, 1953), and migration, as well as of scholarly production (Torres-Abreu, et al, 2019),

\footnotetext{
7 The Trump administration waived these restrictions for a mere ten days between 28 th September and 6th October, 2017.
} 
epistemology (Mignolo, 2002) and even consciousness (Maldonado-Torres, 2007) itself. Food sovereignty in Puerto Rico is enacted at a small scale by diverse groups of very committed people working under severe structural constraints that include the intensifying effects of climate change (Reidmiller, et al [eds], 2018). Under the sign of crisis, both culture and nature are inscribed within gendered (Peller, 2016) and racialised (Lloréns, 2019) economies of praxis in relation to intensifying modes of oppression and resistance. Food autonomy is perceptible as a possibility only at the margins; in the informal economy.

Though it is a precarious life, much work carried out under the sign of agroecology in Puerto Rico offers a model of decolonial action. Small farmers face myriad practical difficulties. They also carry the aspirations of many whose dreams of a different Puerto Rico ride on their continued ability to overcome or negotiate these challenges. Prioritising small-scale farming and working towards food autonomy are fundamental to leftist politics in Puerto Rico today. But the process goes against every notion of progress engrained in generations of Puerto Ricans who learned to think of cement as a manifestation of cleanliness, progress, and modernity. Farming as a political object also inflames historical tensions with regards to the relations between place, race, gender, and identity. Yet, undeniably, the agro-ecology movement has created new hope.

Some land (and water) is claimed for sustenance by people who live in the margins of both industrial and tourist economies. Agriculture, beekeeping, fishing, and poultry farming within these marginalised social sectors continue as everyday practices even under significant limitations with less and more intensive types of production and commodification. In fact, many people rely on small-scale agricultural production and backyard farming for their regular sustenance. I argue that these ordinary sites of selfreproduction in Puerto Rico are part of an Other Caribbean (Hannerz, 1974).

Forms of food production based on the use of rescued lands, public areas, or the liminal spaces between dwellings, for example, are not accounted for in the $10-15 \%$ of food that is commonly cited as being produced and consumed in Puerto Rico. This is because these food items never enter the market as commodities. Rather, they circulate within informal or extended kin networks, forming part of gift or salvage economies (Schneider and Niederle, 2010) that are not factored into statistics based on consumption rates and the point of origin of consumer products (Trauger, 2014).

The notion of an Other Caribbean constituted by marginal areas of economic and social reproduction offers us a way to move through the historical geographies of imperial neglect generated by European and US American colonialism in the Caribbean with the intention not only of historicising the contemporary forms of imperial duress that afflict Puerto Rico and the US Virgin Islands as US territories, but more importantly, of tracing the alternate cartographies of survival that subtend and transcend them.

What work does food sovereignty as a political object and as a model of decolonial action perform in the context of the lack of state sovereignty in Puerto Rico? Scholars have noted how the terms of food sovereignty (Edelman et al 2014), autonomy (Simon-Rojo et al, 2018), resiliency (Bonds, 2018), and sustainability (Davenport et al, 2019) have been co-opted, even as their resonance has grown. Whatever the precise term, we must question the limits of selfsufficiency within the context of a lack of democracy and political autonomy in Puerto Rico and the ways these discourses can be used to promote neoliberal ideas of individual responsibility, especially when faced with large-scale destructive phenomena like hurricanes 
and militarised disaster recovery processes. These are urgent questions, the more that agroecology and small scale farming become increasingly significant as sites of resistance to the genocidal impulse demonstrated by the US in Puerto Rico after Maria.

\section{Conclusion - an Other Puerto Rico}

Puerto Rican leftists face a thorny conundrum; how to develop a social praxis of decolonisation within a political context of ongoing colonialism. One way to address this disjuncture is to distinguish (as the late Samir Amin urged us to do) between forms of popular sovereignty and bourgeois liberal notions of state sovereignty (Amin, 2017). Diverse forms of popular sovereignty manifested in the wake of Hurricane Maria, from autonomous efforts to restore communities and farms, to massive protests that emerged organically in July of 2019 and were seen as leaderless but were actually leader-full (Ransby, 2015) and heavily influenced by the experience with auto-gestión after Maria. While these ebullient protests represented an important political turning point for Puerto Rico, the underlying colonial structures remain unchanged. Within the enduring disaster that is 527 years of colonialism, Puerto Ricans are forging decolonial praxis as we continue to develop creative and substantive expressions, forms of resistance, survival, knowledge production, and solidarity that are capable of inspiring and resonating with people around the world.

\section{BIBLIOGRAPHY}

Acevedo, N, Gutiérrez, G and Ramos, A.R (2019) 'Puerto Ricans flood streets, demand resignation of governor in huge protest', NBC News 22nd July 22: https://www.nbcnews.com/nightly-news/video/puerto-ricans-flood-streets-demandresignation-of-governor-in-huge-protest-64319045590 - accessed 9th October 2019

Allyn, B (2019) 'FBI Arrests Former Top Puerto Rico Officials in Government Corruption Scandal', NPR 11th July: https://www.npr.org/2019/o7/11/740596170/fbi-arrests-former-toppuerto-rico-officials-in-government-corruption-scandal - accessed 9th October 2019

Alvarado, J and Suárez Torres, L (2019) 'Puerto Rico Supreme Court rules Pierluisi’s swearingin as governor unconstitutional', Caribbean Business 7 th August: https://caribbeanbusiness.com/puerto-rico-supreme-court-rules-pierluisis-swearing-in-asgovernor-unconstitutional/ - accessed 9th October 2019

Amin, S (2017) 'The Sovereign Popular Project; The Alternative to Liberal Globalization', Journal of Labor and Society v2o n1: 7-22

Anders, B and Bollettino, V (2018) 'Military mission in Puerto Rico after hurricane was better than critics say but suffered flaws', The Conversation 3oth March: https://theconversation.com/military-mission-in-puerto-rico-after-hurricane-was-betterthan-critics-say-but-suffered-flaws-91558 - accessed 31st August 2019

Ayala, C.J (1996) 'The Decline of the Plantation Economy and the Puerto Rican Migration of the 1950s', Latino Studies Journal v7 nı: 61-9o 
Ayala, C and Bernabe, R (2009) Puerto Rico in the American Century: A History since 1898, Chapel Hill: University of North Carolina Press

Benach, J, Rivera Díaz, M, Muñoz, N.J et al (2019) 'What the Puerto Rican hurricanes make visible: Chronicle of a public health disaster foretold', Social Science $\mathcal{E}$ Medicine n238/112367: 1-10

Berlant, L (2011) Cruel Optimism, Durham: Duke University Press

Bonds, A (2018) 'Refusing resilience: the racialization of risk and resilience', Urban Geography v39 n8: $1285-1291$

Brusi-Gil De Lamadrid, R (2011) 'The University of Puerto Rico: A Testing Ground for the Neoliberal State', NACLA Report on the Americas v44 n2: 7-10

Cabán, P (2002) 'Puerto Rico: State Formation in a Colonial Context,' Caribbean Studies v3o n2: $170-215$

----- (2018) 'PROMESA, Puerto Rico and the American Empire,' Latino Studies v16 n2: 161-184

Caraballo-Cueto, J (2015) 'Some Determinants of the Puerto Rican Migration to the US in 1950-2014', CIDE digital v6 n1: 22-30

CCR (National Cancer Institute Center for Cancer Research) (2017) News 12th January: https://ccr.cancer.gov/news/article/finding-relief-in-the-aftermath-of-hurricane-maria-apatients-journey-from-puerto-rico-to-the-national-institutes-of-health - accessed 1oth October 2019

Colón-Ramos, U, Roess, A, Robien, K et al (forthcoming 2019) 'Foods Distributed During Federal Disaster Relief Response in Puerto Rico After Hurricane Maria Did Not Fully Meet Federal Nutrition Recommendations,' Journal of the Academy of Nutrition and Dietetics

Cortés, J (2018) 'Necromedia, Haunting, and Public Mourning in the Puerto Rican Debt State: The Case of "Los Muertos", Journal of Latin American Cultural Studies v27 n3: $357-369$

Davenport, S.G and Mishtal, J (2019) 'Whose Sustainability? An Analysis of a Community Farming Program's Food Justice and Environmental Sustainability Agenda', Culture, Agriculture, Food and Environment v41 nı: 56-65

De Onís, C.M (2018) 'Fueling and delinking from energy coloniality in Puerto Rico,' Journal of Applied Communication Research v46 n5: 535-56o

Díaz-Quiñones, A (1991) ‘Puerto Rico: Cultura, memoria y diáspora', Nueva Sociedad v116: 153158

Dietz, J (1986) Economic History of Puerto Rico: Institutional Change and Capitalist Development, Princeton: Princeton University Press

Duffy Burnett, C and Marshall, B (eds) (2001) Foreign, in a Domestic Sense: Puerto Rico, American Expansion, and the Constitution, Durham: Duke University Press 
Edelman, M, Weis, T, Baviskar, A et al (2014) 'Introduction: critical perspectives on food sovereignty', Journal of Peasant Studies v41 n6: 911-931

Feuer, A (2012) 'Occupy Sandy: A Movement Moves to Relief', New York Times November 9th: https://www.nytimes.com/2012/11/11/nyregion/where-fema-fell-short-occupy-sandywas-there.html - accessed 9th October 2019

Fletcher, R (2019) 'Capitalizing on chaos: Climate change and disaster capitalism', Ephemera v12 n1/2: 97-112

Gaillard, J.C (2018) 'Disaster studies inside out', Disasters v43 nS1: S7-S17

Garriga-López, A.M (2018) 'A School of Addicts: the Coloniality of Addiction in Puerto Rico', in Collins, J and McGranahan, C.A (eds), Ethnographies of US Empire, Durham: Duke University Press: 93-111

Garriga-López, A.M and Uperesa, F.L (2017) 'Contested Sovereignties: Puerto Rico and American Samoa', in Negrón-Muntaner, F (ed) Sovereign Acts: Contesting Colonialism Across Indigenous Nations and Latinx America, University of Arizona Press: 39-81

Gómez-Barris, M (2017) The Extractive Zone: Social Ecologies and Decolonial Perspectives, Durham: Duke University Press

Gonzales, R (2019) 'Puerto Rico's Justice Secretary Wanda Vasquez Sworn In As Governor' $N P R$ 7th August: https://www.npr.org/2019/o8/o7/749090146/puerto-ricos-supreme-courtrules-pierluisi-unconstitutionally-sworn-in-as-govern — accessed 7th August 2019

Gould, K.A and Lewis, T (2018) 'Green Gentrification and Disaster Capitalism in Barbuda', NACLA Report on the Americas v50 n2: 148-153

Hannerz, U (1974) Caymanian Politics: Structure and style in a changing island society, Stockholm: Universitetet, Socialantropologiska institutionen

Hinojosa, J (2018) 'Two Sides of the Coin of Puerto Rican Migration: Depopulation in Puerto Rico and the Revival of the Diaspora', CENTRO: Journal of the Center for Puerto Rican Studies v30 n3: 230-253

Hooper, C (2017) 'It Took Comfort 39 Days to Get Pierside in Puerto Rico. That's a Nationalsecurity Problem', Defense One: 6th November:

https://www.defenseone.com/ideas/2017/11/hospital-ships-hurricane-maria/142319/ accessed 31st August 2019

Hunter, J and Arbona, S (1995) 'Paradise Lost: An Introduction to the Geography of Water Pollution in Puerto Rico', Social Science and Medicine v4o nı: 1331-1355

Joseph, M (2002) Against the Romance of Community, Minneapolis: University of Minnesota Press 
Karlin, M (2017) 'Economic Inequalities and Climate Apartheid: Ashley Dawson on "Extreme Cities"', Truthout 29th October: https://truthout.org/articles/economic-inequalities-andclimate-apartheid-ashley-dawson-on-extreme-cities/ - accessed 15th September 2019

Kishore, N, Marqués, D, Mahmud, A et al (2018) 'Mortality in Puerto Rico after Hurricane Maria', New England Journal of Medicine v379: 162-170

Klein, B (2019) 'Trump slams Puerto Rico as impending storm intensifies', CNN 28th August: https://edition.cnn.com/2019/o8/28/politics/donald-trump-dorian-carmen-yulincruz/index.html — accessed 28 August 2019

Klein, N (2007) The Shock Doctrine: The Rise of Disaster Capitalism, New York: Metropolitan Books

----- (2018) The Battle for Paradise: Puerto Rico Takes on the Disaster Capitalists, Chicago: Haymarket Books

Laguarta Ramírez, J.A (2018) 'Riding the perennial gale: working-class Puerto Ricans and the involution of colonial capitalism', Dialectical Anthropology v42 n2, 117-129

Lapp, M (1995) 'The Rise and Fall of Puerto Rico as a Social Laboratory, 1945-1965', Social Science History v19 n2: 169-199

Lauria-Periccelli, A (1989) 'A Study in Historical and Critical Anthropology: The Making of The People of Puerto Rico', (unpublished) PhD thesis, The New School for Social Research, New York

Lebrón, M and Arbona, J (2018) 'Resisting Debt and Colonial Disaster in Post-Maria Puerto Rico', The Funambulist v16: https://thefunambulist.net/articles/guest-columnists - accessed 9th October 2019

Lewis, G.K (1963) Puerto Rico: Freedom and Power in the Caribbean, New York and London: Monthly Review Press

Llenín Figueroa, B (2019) 'From Puerto Rico: The Maroons Are Deathless, We Are Deathless', Radical History Review:

https://www.radicalhistoryreview.org/abusablepast/?p=3145 -accessed 29th August 2019

Lloréns, $H$ (2017) 'The Making of a Community Activist', Sapiens 5th May: https://www.sapiens.org/culture/jobos-bay-community-activist/ - accessed on 15th September 2019

----- (2019) 'The Race of Disaster: Black Communities and the Crisis in Puerto Rico', Black Perspectives 17th April: https://www.aaihs.org/the-race-of-disaster-black-communities-andthe-crisis-in-puerto-rico/ - accessed 15th September 2019

Llórens Vélez, E (2019a) 'Trump sends nominations of current Puerto Rico fiscal board members to Senate', Caribbean Business 18th June: https://caribbeanbusiness.com/trumpsends-nomination-of-current-puerto-rico-fiscal-board-members-to-senate/ - accessed 9th October 2019 
----- (2019b) 'Court gives Trump, Senate 9o days to validate Puerto Rico fiscal board', Caribbean Business, 15th February: https://caribbeanbusiness.com/district-court-rulespuerto-rico-fiscal-board-members-unconstitutionally-appointed/ - accessed 9th October 2019

Maldonado-Torres, $\mathrm{N}$ (2007) 'On the Coloniality of Being: Contributions to the development of a concept', Cultural Studies v21 n2-3: 240-270

----- (2016) 'Outline of Ten Theses on Coloniality and Decoloniality', Fondation Frantz Fanon: http://fondation-frantzfanon.com/outline-of-ten-theses-on-coloniality-and-decoloniality/ accessed on 15th September 2019

Margolis, J (2016) 'Puerto Rico's debt crisis takes aim at kids and the sick', The World (Public Radio International) 16th June: https://www.pri.org/stories/2016-o6-16/puerto-ricos-debtcrisis-impacting-health-care-and-children-special-needs - accessed 15th September 2019

Marston-Firmino, A (2019) 'The Storm Next Time', Theater v49 n1: 3-5

Mazzei, P and Robles, F (2019) 'Ricardo Roselló, Puerto Rico's Governor, Resigns After Protests', New York Times 24th July: https://www.nytimes.com/2019/o7/24/us/rossellopuerto-rico-governor-resigns.html - accessed 15th September 2019

McCune, N, Perfecto, I, Vandermeer, J and Avilés, K.A (2018) 'Disaster Colonialism and Agroecological Brigades in Post-Disaster Puerto Rico', TNI (The Transnational Institute): https://www.tni.org/my/node/24252 - accessed September 15th, 2019

Meléndez-Badillo, J (2019) 'Commemorating May Day in Puerto Rico', NACLA Report on the Americas v51 n3: 301-305

Meléndez, E and Venator-Santiago, C (2018) 'Introduction to Puerto Rico Post-Hurricane Maria: Origins and Consequences of a Crisis', CENTRO: Journal for the Center for Puerto Rican Studies v30 n3: 5-29

Mignolo, W (2002) 'Postoccidentalismo: Las Epistemologias Fronterizas y el Dilema de los Estudios (Latinoamericanos) de Área', Revista Iberoamericana v68 n2oo: 847-864

Mintz, S (1953) 'The Culture History of a Puerto Rican Sugar Cane Plantation: 1876-1949', The Hispanic American Historical Review v33 n2: 224-251

Molinari, S (2019) 'Authenticating Loss and Contesting Recovery: FEMA and the Politics of Colonial Disaster Management', in Bonilla, Y and Lebrón, M (eds) Aftershocks of Disaster: Puerto Rico Before and After the Storm, Chicago: Haymarket Books: 285-297

Mora, M.T, Dávila, A and Rodríguez, H (2018) Population, Migration, and Socioeconomic Outcomes among Island and Mainland Puerto Ricans: La Crisis Boricua, Boulder, New York and London: Lexington Books

Morales, E (2019) 'Feminist and LGBTQ Activists Are Leading the Insurrection in Puerto Rico', The Nation 2nd August: https://www.thenation.com/article/puerto-rico-insurrectionfeminists-lgbtq/ - accessed 9th October 2019 
Mulligan, J (2014) Unmanageable Care: An Ethnography of Health Care Privatization in Puerto Rico, New York and London: New York University Press

Negrón-Muntaner, F (2018) 'Blackout: What Darkness Illuminated in Puerto Rico', Politics \& Letters, 2nd March: http://quarterly.politicsslashletters.org/blackout-darkness-illuminatedpuerto-rico/ - accessed 9th October 2019

Newman, L (2019) 'Trump revives Monroe Doctrine as warning to China and Russia', Aljazeera News: https://www.aljazeera.com/news/2019/o6/trump-revives-monroe-doctrinewarning-china-russia-190619060326024.html - accessed on 15th September 2019

Noboa Ortega, P (2019) 'Psychoanalysis as a Political Act after Maria', in Bonilla, Y and Lebrón, M (eds) Aftershocks of Disaster: Puerto Rico Before and After the Storm, Chicago: Haymarket Books: 271-284

Noboa Ortega, P and Soto Arzat, A (2018) 'Psychoanalysis and Research for Communities', Cruce 5th November: 10-21

Oliva Campos, C and Prevost, G (2019) 'The Trump Administration in Latin America: Continuity and Change', International Journal of Cuban Studies v11 n1: 13-23

Ora Bannan, N.L (2017) 'Puerto Rico's Double Devastation: Hurricanes and Austerity', Huffington Post 26th September: https://www.huffpost.com/entry/puerto-ricos-doubledevastation-hurricanes-and-austerity_b_59ca85ofe4bocdc7733531bo - accessed 15th September 2019

Orengo-Aguayo, R, Stewart, R.W and de Arellano, M.A (2019) 'Disaster Exposure and Mental Health Among Puerto Rican Youths After Hurricane Maria', JAMA Network Open 26th April: https://jamanetwork.com/journals/jamanetworkopen/fullarticle/2731679 - accessed 15th September 2019

Panourgia, N (2011) 'Tightrope (In the Manner of Antonio Lauria-Periccelli)', Transforming Anthropology v19 n2: 146-153

Parés Arroyo, M (2018) 'La fuga de médicos amenaza la salud', El Nuevo Día 23rd July: https://www.elnuevodia.com/noticias/locales/nota/lafugademedicosamenazalasalud2436908/ - accessed 9th October 2019

Patron, M (2017) 'Puerto Rico's Exodus of Doctors Adds Health Care Strain to Dire Financial Crisis', NBC News 9th August: https://www.nbcnews.com/news/latino/puerto-rico-sexodus-doctors-adds-health-care-strain-dire-n783776 - accessed on 15th September 2019

Peller, B (2016) 'Self-Reproduction and the Oaxaca Commune', ROAR Magazine n1: https://roarmag.org/magazine/reproducing-the-oaxaca-commune/ - accessed 15th September 2019

Pérez-Lizasuain, C.J (2018) 'Entering the Contact Zone? Between Colonialism, Neoliberal Resilience and the Possibility of Emancipatory Politics in Puerto Rico's Post Maria', Alternautas v5 n2: 43-55 
Primerahora (2016) 'Despiden al ELA con una esquela', Primerahora 25th July: https://www.primerahora.com/noticias/gobiernopolitica/nota/despidenalelaconunaesquel a-1166440/ - accessed 1oth October 2019

Puerto Rico Report (2019) 'Congress Grapples with Upcoming Medicaid Cliff, Puerto Rico Report: https://www.puertoricoreport.com/congress-grapples-with-upcoming-medicaidcliff/ - accessed 15th September 2019

Ramos, M (2019) 'El PNP mató la estadidad', El Vocero de Puerto Rico 2nd August: https://www.elvocero.com/opinion/el-pnp-mat-la-estadidad/article_b8c1286a-b4c6-11e98cd8-df6eac6fogo8.html - accessed 9th October 2019

Ramos-Zayas, A. Y (2010) 'Gendering "Latino Public Intellectuals": Personal Narratives in the Ethnography of Elena Padilla', in Rua, M (ed) Latino Urban Ethnography and the Work of Elena Padilla, Urbana, Chicago and Springfield: University of Illinois Press: 178-206

Ransby, B (2015) 'Ella Taught Me: Shattering the Myth of the Leaderless Movement', Colorlines 12th June: https://www.colorlines.com/articles/ella-taught-me-shattering-mythleaderless-movement - accessed on 15th September 2019

Reidmiller, D.R, Avery, C.W, Easterling, D.R et al (eds) (2018) Fourth National Climate Assessment, Washington, DC: US Global Change Research Program

Rodríguez-Díaz, C.E (2018) 'Maria in Puerto Rico: Natural Disaster in a Colonial Archipelago', American Journal of Public Health v108 n1: 30-32

Rodríguez Soto, I (2018) 'Colonialism’s Orchestrated Disasters in Puerto Rico', Anthropology News gth May:

https://anthrosource.onlinelibrary.wiley.com/doi/10.1111/AN.711 — accessed 15th September 2019

Said, E (1978) Orientalism, New York: Pantheon Books

Scaramutti, C, Salas-Wright, C.P, Vos, S.R and Schwartz, S.J (2019) 'The Mental Health Impact of Hurricane Maria on Puerto Ricans in Puerto Rico and Florida', Disaster Medicine and Public Health Preparedness v13 n1: 24-27

Schneider, S and Niederle, P.A (2010) 'Resistance strategies and diversification of rural livelihoods: the construction of autonomy among Brazilian family farmers', The Journal of Peasant Studies v37 n2: 379-405

Scott, D (2004) Conscripts of Modernity: The Tragedy of Colonial Enlightenment, Durham: Duke University Press

Sullivan, L (2018) 'FEMA Blamed Delays in Puerto Rico On Maria; Agency Records Tell Another Story', NPR 14th June: https://www.npr.org/2018/o6/14/608588161/fema-blameddelays-in-puerto-rico-on-maria-agency-records-tell-another-story - accessed $15^{\text {th }}$ September 2019 
Sutter, J.D (2018) '130,ooo left Puerto Rico after Hurricane Maria, Census Bureau Say', CNN 19th December: https://edition.cnn.com/2018/12/19/health/sutter-puerto-rico-censusupdate/index.html - accessed on 15th September 2019

Thomas, L (2014) Desire and Disaster in New Orleans: Tourism, Race, and Historical Memory, Durham: Duke University Press

Tormos, F (2018) 'The Politics of Survival in Puerto Rico: The Balance of Forces in the Wake of Hurricane Maria,' Alternautas v5 n2: 79-94

Tormos-Aponte, F (2019) 'Puerto Rico Rises,' Jacobin 17th July: https://jacobinmag.com/2019/o7/puerto-rico-ricardo-rossello-telegram-chat-hurricanemaria-protest-demonstration - accessed 15th September 2019

Torres-Abreu, A, Reyes-Díaz, A, Molina Rodríguez, M and Soto Santiago, F (2019) ‘Exploring Local Ontologies: Knowledge, Practice, and Community Views Regarding Puerto Rico's Northeast Ecological Corridor', Human Organization v78 n3: 192-204

Trauger, A (2014) 'Toward a political geography of food sovereignty: transforming territory, exchange and power in the liberal sovereign state', The Journal of Peasant Studies v41 n2: 11311152

Trías Monge, J (1995) 'El Estado Libre Asociado Ante los Tribunales, 1952-1994', Revista Jurídica Universidad de Puerto Rico v64 n1: 1-5o

---- (1997) Puerto Rico: The Trials of the Oldest Colony in the World, New Haven: Yale University Press

Tuck, E and Yang, K.W (2012) 'Decolonization is not a metaphor', Decolonization v1 nı: 1-40

Underhill, H (1961) 'Puerto Rico: A Showcase of Democracy', The Diplomat January: 16, 36

Univisión (2016) 'Publican esquela por la 'muerte' del Estado Libre Asociado en Puerto Rico', Univisión 25th July: https://www.univision.com/local/puerto-rico-wlii/publican-esquelapor-la-muerte-del-estado-libre-asociado-en-puerto-rico - accessed 15th September 2019

Villanueva, J, Cobián, M and Rodríguez, F (2018) 'San Juan, the Fragile City: Finance Capital, Class, and the Making of Puerto Rico's Economic Crisis', Antipode v5o n5: 1415-1437

Vincens, A.J (2019) 'Former Puerto Rico Education Secretary Arrested on Federal Corruption Charges', Mother Jones 1oth July: https://www.motherjones.com/politics/2019/o7/juliakeheher-puerto-rico-education-secretary-corruption/ - accessed 15th September 2019

Yglesias, M (2017) 'The Jones Act, the obscure 1920 shipping regulation strangling Puerto Rico, explained', Vox 27th September: https://www.vox.com/policy-andpolitics/2017/9/27/16373484/jones-act-puerto-rico - accessed on 15th September 2019 